J. Product. \& Dev., 14(1): 51 - 62 (2009)

\title{
EVALUATION AND VALIDATION OF TEB-CAST FORECAST SYSTEM TO MANAGE TOMATO EARLY BLIGHT IN EGYPT
}

\author{
Sahar M.A. Afifi; A. M. Zayan and M. A. Khatab \\ Plant Pathology Research Institute, Agricultural Research Center, Giza, \\ Egypt. \\ E-mail:profmafifi@yahoo.com
}

\begin{abstract}
Tomato (Lycopersicon esculentum Mill.) is considered one of the main vegetable cash crop for both local consumption and exportation in Egypt. The most important disease infect tomato plants is early blight caused by Alternaria solani which also attacks several nightshade crops including potato and eggplant. Under favourable weather conditions the disease cycle takes about one week.This rapid reproduction cycle can expand the disease so rapidly and completely defoliate tomato plants causing a severe losses in yield. Therefore, a 7-10 day spray schedule with protecting fungicides is a traditional and effective system to control tomato early blight. Consumer concern about agro-chemical residues is strong in Egypt, and particularly relevant for fresh consumed products, including tomato. This consumer concern for food safety and the environment has lead to certified schemes for good agricultural practices such as disease forecast. A computerized forecast model named by the authors ( TEB-Cast) is an integral linking based on short term observations over several tomato growing seasons, analyzing the correlation between 24 hour microclimate data collected throughout real time automatic Agroweather station (Adcon Telemetry A733 AddWave ), was evaluated and validated under both computer lab. (workstation) and open field in 2005 and 2006 growing seasons. The results indicated that TEB-Cast forecast model correctly timed the first spray and the disease daily infection potential and significantly reduced the number of sprays compared with the routine schedule fungicide applications in both 2005 and 2006 growing seasons respectively. The basic roles of system analysis for model evaluation and validation are discussed in details.
\end{abstract}

Key words: Evaluation, validation, teb-cast, forecast system, manage tomato, early blight, Egypt 


\section{INTRODUCTION}

Tomato( Lycopersicon esculentum Mill.) is one of the most widely produced and consumed vegetables in the world, both for the fresh fruit market and the processed food industries, moreover tomato is considered a major contributor to the fruit vegetable diet of humans. Tomato is cultivated in essentially all countries either in fields or in protected culture (Atherton and Rudich, 1986). Egypt is the largest producer of tomato on the African continent, the area cultivated of tomato crop yearly amounts about 460.000 feddans with a total production of slightly over 6 million tons (Anon., 2004). So that it is of great importance to try to increase fruit yield and quality. Early blight of tomato caused by the necrotrophic fungus Alternaria solani (Ellis \& Martin) Jones \& Grout is one of the most common foliar diseases of tomato. The disease can occur over a wide range of climatic conditions, but is most prominent in areas with heavy dew, rainfall and high relative humidity. The disease cycle is about five to seven days(Shuman and Joel Lee, 1995), so numerous repeating cycles can occur during the long growing season. On tomato it causes damping-off of seedlings, later collar rot, leaf spots, stem lesions and fruit rot. Infection of the plants can result in a complete loss of the crop as yields are reduced by destruction of foliage and the fruits are damaged directly by the pathogen and by sun blotch on defoliated plants (Jones, et al., 1993; Rotem, 1998 and Foolad, et al., 2000).

In Egypt, tomato early blight occurs yearly and causes a significant crop loss especially in the northern Delta and in sandy new reclaimed areas during the tomato winter season when the disease environmental favourable conditions are showed up. No major gene resistance towards early blight is known, genetic sources for partial resistance have been identified within wild species of tomato. The resulting lines from crosses of tomato with these wild species have still no satisfying crop qualities (Vloutoglou \& Kalogerakis, 2000).Therefore, current effectively control recommendations for such disease relay on the use of fungicides spray programs. These programs are often based on calendar systems; 7-10 day sprays (Fadl et al., 1985).

Minimizing fungicide use is a goal of growers, processors, and consumers. Disease management programs that reduce the number of fungicide applications also reduce grower costs, potential residues on the produce and risk of development of fungicide resistance in the pathogens. One way to reduce the number of necessary fungicide applications without compromising disease control is through the use of disease warning systems that predict potential outbreaks or increases in disease severity based on the weather. Monitoring of weather conditions within the plant canopy is possible by automated weather stations, real-time weather data can be 
transmitted from automated weather stations at remote sites to personal computers via telephone modems or by radio telemetry. Many scientific efforts have been done all over the world to forecast tomato early blight, or to provide systems that support the spray decision and replace the routine prophylactic spraying. All forecasts are based on determining the probability of weather that will favor infection and to produce risk warning and spray recommendations (Madden et al., 1978; Pitblado, 1992; Gleason et al.,1995 and Waals et al., 2003).

A computerized model TEB-Cast simulates the development of tomato early blight on the basis of short-term observations of microclimatic factors. The input variables to the model are: temperature, relative humidity, precipitation, wind speed, global radiation and leaf wetness for the daily disease infection potential (DDIP). This study was focused on the evaluation and validation of TEB-Cast, the first Egyptian computerized forecasting model for better disease control with minimum fungicide use. It works by forecast the most appropriate spray intervals to manage effective control of tomato early blight, compared with routine fungicide applications.

\section{MATERIALS AND METHODS}

\section{Weather monitoring:}

Automated, portable and solar powered in-crop weather stations (Adcon Telemetry A733) (Figure 1) were used to monitor the microclimatological conditions. High technology, sensitive sensors transmitted the digital data up to $20 \mathrm{~km}$ in distance, on average every 15 minutes, via a personal computer using radio waves. In this way, data on temperature, relative humidity, wind speed, leaf wetness, precipitation and global radiation were collected from tomato canopy. The station is equipped with central base station (Figure 2) which served as a: data collection centre (receiver) to receive and save the collected data up to 50 days and to run advantage software which allowed simple interpretation of the readings using a graph and detailed list of chosen items.

\section{Tomato early blight forecast model:}

A computerized simulation model named by the authors TEBCast,(Figure 3) was designed and tested several times under laboratory conditions before switching to a validation phase under field conditions at Nobaryia (Behera Governorate) during the 2005 and 2006 tomato growing seasons. These experiments were used to figure out how well such a model can forecast the daily disease infection potential (DDIP), which was revised and refined based on these findings. Frequently, disease control ( times of 


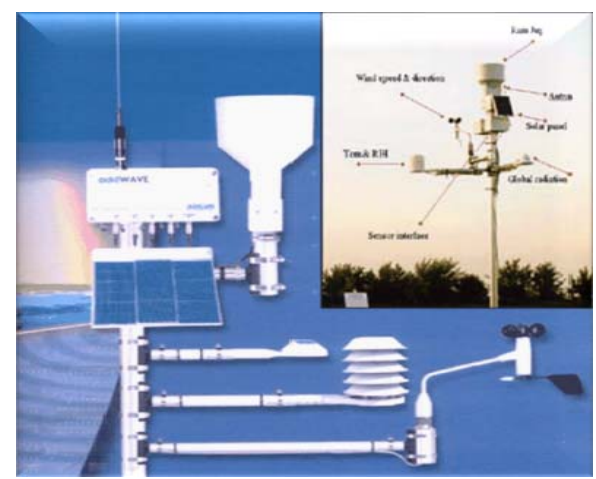

Figure 1. Automated in crop weather station (Adcon A733).

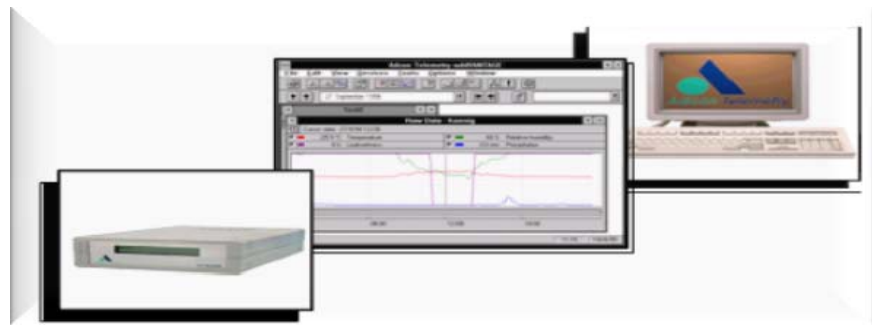

Figure 2. The base station (Receiver, PC, and Advantage Software) Data is instantly plotted for easy examination of weather data. Time line indicates values where it intersects data lines.

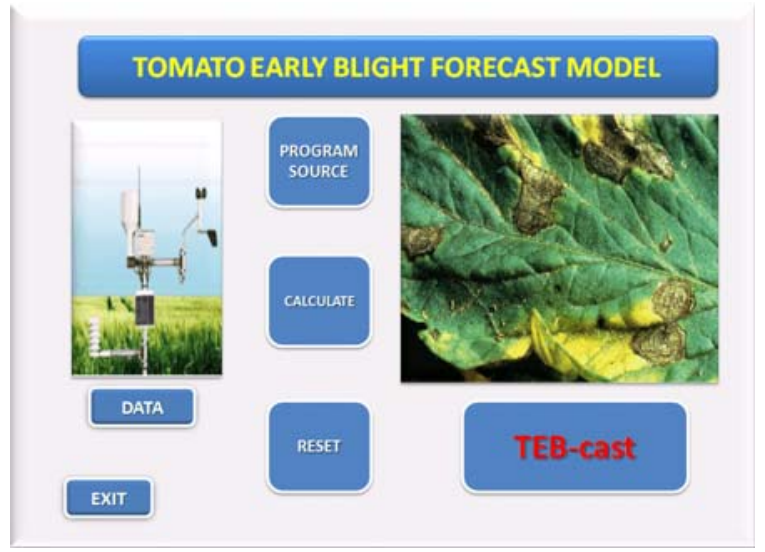

Figure 3. TEB-Cast model's interface for tomato early blight in Egypt. 
sprays) of tomato treated according to the model recommendations was compared to disease managed by traditional routine spray schedules.

\section{The model system analysis:}

TEB-Cast model, presented as a flowchart is a creation and designation of a computerized simulation model, based on daily short-term observations (hourly weather data) analyzing the correlation between the input variables of microclimatological factors such as temperature, relative humidity, leaf wetness, precipitation, global radiation and wind speed. The model uses these factors to calculate the actual time of primary infection of tomato early blight causal agent Alternaria solani. Then, the model outputs a daily announcement for the daily disease infection potential (DDIP) as a warning message (spray or don't spray) to guide the fungicides application for perfect disease control in the appropriate time. The model evaluation and validation follows the basic rules of system analysis to identify events (A and B) for spore germination according to $\mathrm{RH}$ and leaf wetness, respectively. The model is activated at pre-emergence phase, and tries to detect the events $\mathrm{A}$ and $\mathrm{B}$ which are defined as: Event $\mathrm{A}$ is triggered when the model detects at least $\mathrm{X}$ accumulated dynamic summation hours of $\mathrm{RH}$ $>90 \%$ and temperature between $\mathrm{Y}$ and $\mathrm{Z}$ according to the data tabulated in Table 1. While event $\mathrm{B}$ is triggered when the model detects at least $\mathrm{X}$ accumulated dynamic summation hours leaf wetness $>80 \mathrm{U}$ and / or precipitation $>0.2 \mathrm{~mm} /$ hour and temperature between $\mathrm{Y}$ and $\mathrm{Z}$ according to the data tabulated in Table 2 . In addition, using the model system analysis brings an extension to the model, that applies the same rules not only to identify the first critical phase of the season (correct time for primary infection), but also to issue warnings message for secondary daily disease infection potential (DDIP) throughout the whole growing season.

\section{Model validation:}

Field experiments were conducted at Nobaryia (Behera Governorate) during two successive growing seasons; 2005 and 2006 in commercial tomato fields of the susceptible cultivar (UC97), to evaluate and validate the TEB-Cast model in managing tomato early blight compared with the recommended routine application schedule. Such experiments were designed as randomized complete blocks and the area of each plot was $12 \mathrm{~m}^{2}$ $(3.0 \times 4.0 \mathrm{~m})$, Four replicates were used for each treatment and non-treated plots (sprayed with only water) served as control. The following three treatments were tested: (i) a full-schedule fungicide program, in which plants were sprayed every 10 days ; (ii) a full-schedule fungicide program, in which plants were sprayed every 7 days; (iii) spraying when nominal use of the forecasting system indicated that a spray application was needed and 


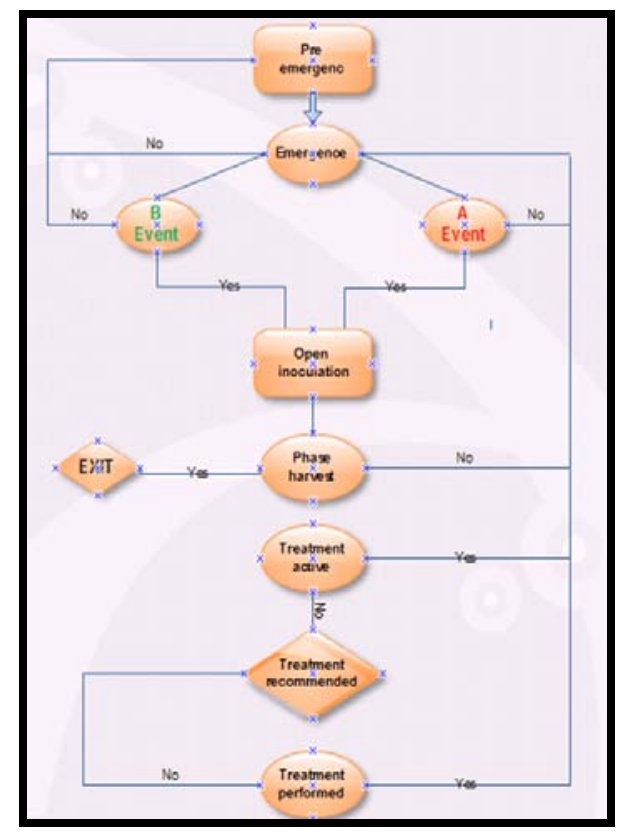

Figure 4. Flowchart of TEB-Cast model's system analysis.

Table 1. The basic rules of system analysis to identify event $A$.

\begin{tabular}{|c|c|l|l|l|}
\hline $\begin{array}{l}\text { Y= Temp. } \\
\text { From: }\end{array}$ & $\begin{array}{l}\text { Z=Temp. } \\
\text { To: }\end{array}$ & $\begin{array}{l}\text { X=4 hours } \\
\text { of } \mathbf{R H}\end{array}$ & $\begin{array}{l}\mathbf{X = 6} \text { hours } \\
\text { of RH }\end{array}$ & $\begin{array}{l}\mathbf{X}=\mathbf{8} \text { hours } \\
\text { of RH }\end{array}$ \\
\hline 26 & 29 & $\begin{array}{l}\text { Event } \mathbf{A} \\
\text { detected }\end{array}$ & & \\
\hline 22 & 25 & & $\begin{array}{l}\text { Event } \mathbf{A} \\
\text { detected }\end{array}$ & \\
\hline 18 & 21 & & & $\begin{array}{l}\text { Event A } \\
\text { detected }\end{array}$ \\
\hline
\end{tabular}

Table 2. The basic rules of system analysis to identify event $B$.

\begin{tabular}{|c|c|l|l|l|}
\hline $\begin{array}{l}\text { Y= Temp. } \\
\text { From: }\end{array}$ & $\begin{array}{l}\text { Z=Temp. } \\
\text { To: }\end{array}$ & $\begin{array}{l}\mathbf{X = 2} \text { hours } \\
\text { of } \mathbf{L ~ W}\end{array}$ & $\begin{array}{l}\mathbf{X = 4} \text { hours } \\
\text { of } \mathbf{R H}\end{array}$ & $\begin{array}{l}\mathbf{X}=\mathbf{6} \text { hours } \\
\text { of RH }\end{array}$ \\
\hline 26 & 29 & $\begin{array}{l}\text { Event } \mathbf{B} \\
\text { detected }\end{array}$ & & \\
\hline 22 & 25 & & $\begin{array}{l}\text { Event } \mathbf{B} \\
\text { detected }\end{array}$ & \\
\hline 18 & 21 & & & $\begin{array}{l}\text { Event } \mathbf{B} \\
\text { detected }\end{array}$ \\
\hline
\end{tabular}


at least 10 days had elapsed since the previous fungicide application. Moreover Ridomil plus 50\% WP ( Metalaxyl + copper ) 150gm / 100L water is considered an effective recommended fungicide for controlling tomato early blight in Egypt ( Fadl et al., 1985), and this was used with both the TEB-Cast forecasting model announcement recommended treatments and the routine application schedule program. Weekly tomatoes field inspection was initiated to ensure clear detection of the early sign of early blight. Microclimate weather data were automatically collected $24 \mathrm{~h}$ a day by the advanced telemetry weather station ( Adcon A733), established within the canopy of tomatoes field as on-site weather monitoring. Disease severity was measured 15 days after the last spray using a randomized sample of one hundred leaves from every plot, control efficacy of both treatments was recorded according to (Horsfall \& Barrat, 1945).

\section{RESULTS}

The results of such investigation pointed out that the TEB-Cast computerized forecast model for tomato early blight, which was adopted according to the roles of system analysis, was successfully validated in Egypt under tomato open field conditions and used a fewer number of fungicide sprays for effectively management of early blight compared with a routine full-schedule fungicide program with both $(7 \mathrm{D})$ and / or $(10 \mathrm{D})$ schedule. Data presented in Figures 5 and 6 indicate that the TEB-Cast model accurately defined the early blight daily infection potential and the daily warning message announcement for the (DDIP) was recommended five times at $7^{\text {th }}, 23^{\text {rd }}$ of Nov., and at $12^{\text {th }}, 17^{\text {th }}, 21^{\text {st }}$ of Dec. 2005. While it was six times at $9^{\text {th }}, 14^{\text {th }}, 26^{\text {th }}$ of Nov., and $13^{\text {th }}, 20^{\text {th }}, 31^{\text {st }}$ of Dec. 2006, respectively. That concluded in three sprays in 2005 and four sprays in 2006 , instead of eight sprays for (7D) and six sprays for (10 D) fungicide program schedule in 2005 and 2006, respectively. Generally, each of the three experimental treatments successfully controlled tomato early blight in both seasons.

\section{DISCUSSION}

Early blight caused by Alternaria solani is a very common and serious foliar disease of tomato crop that can result in leaf defoliation and reduced yields. In Egypt, a forecasting system for early blight on tomato was evaluated for the first time to identify periods when environmental conditions are favorable for early blight development and to provide a schedule for efficient fungicide applications. There is strong evidence that the TEB-Cast computerized forecasting model can be used to determine the 


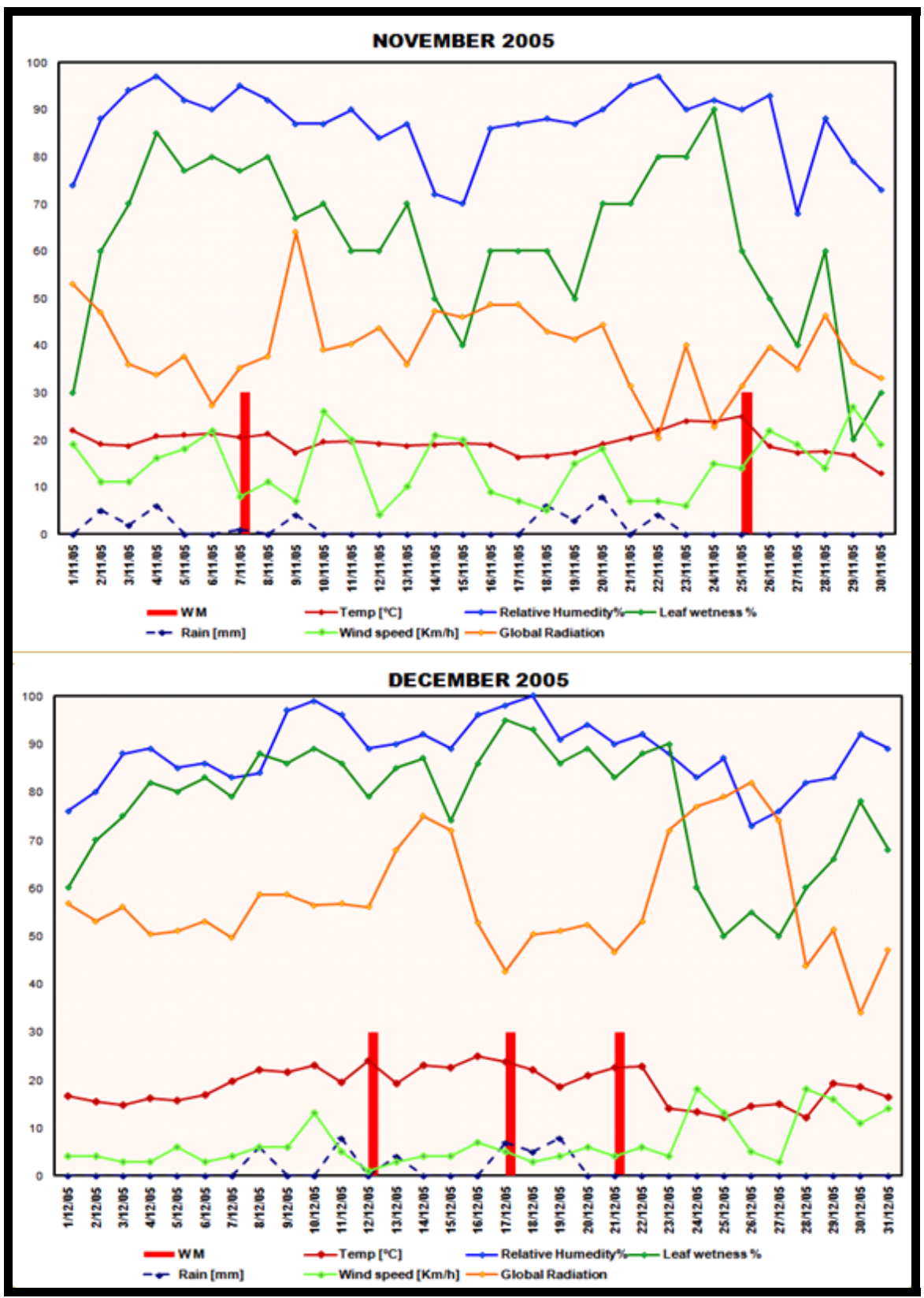

Figure 5. The daily microclimatological factors (TEB-Cast model input variables ) during November and December 2005 tomatoesgrowing season, indicate the warning message of forecast system spray recommendations. 


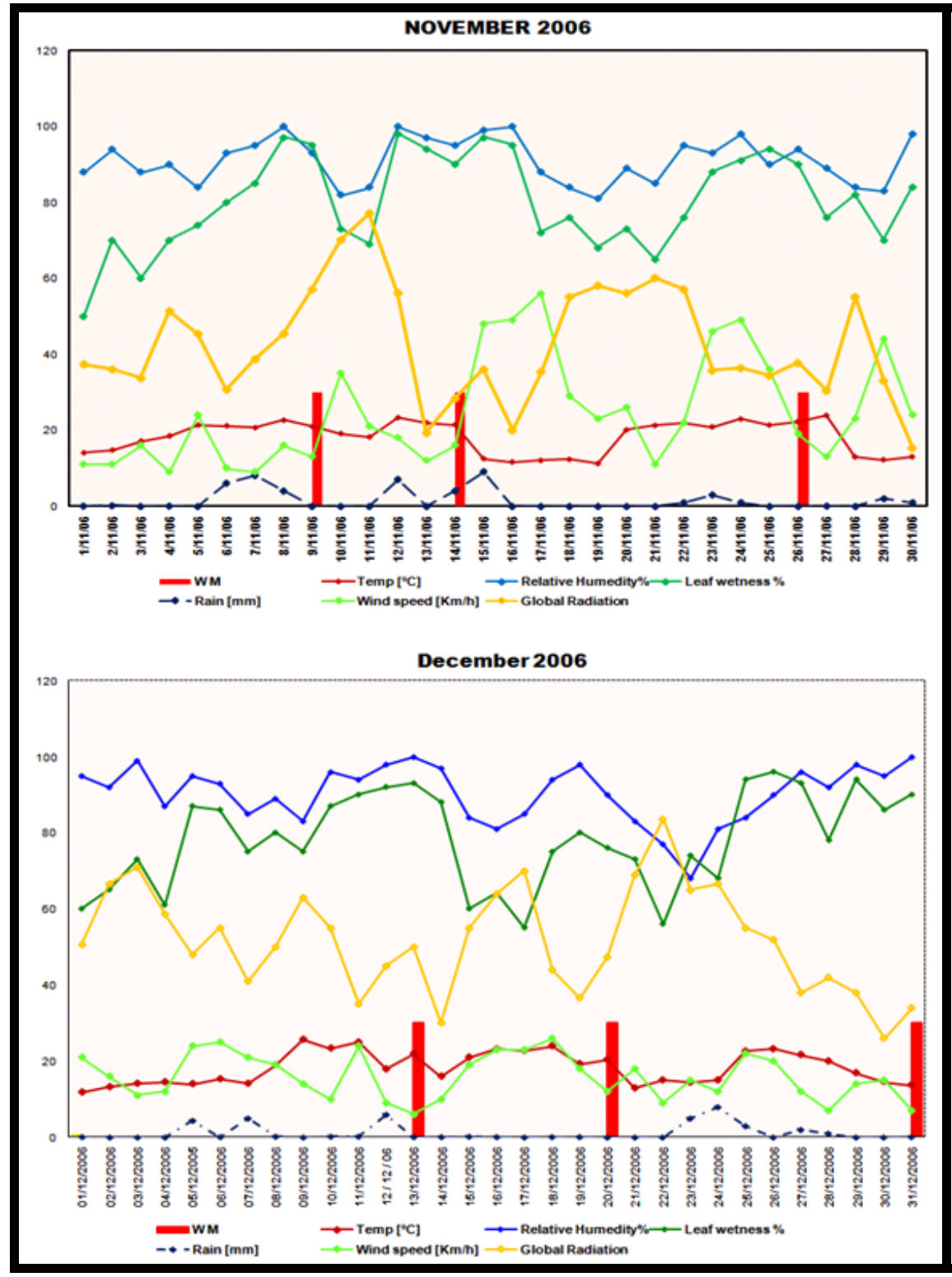

Figure 6. The daily microclimatological factors (TEB-Cast model input variables ) during November and December 2006 tomatoesgrowing season, indicate the warning message of forecast system spray recommendations.

frequency of sprays needed to manage early blight of tomato with fewer number of sprays compared with the recommended routine applications 710 day schedules. The spray schedule produced by the forecasting system provided efficient and effective control of tomato early blight in 2005 and 
2006 growing seasons. Reduction the number of sprays resulted following the TEB-Cast model rather than a 7-10 day schedule when used in two consecutive years were 50- 62.5\% in 2005 and 33.3-50\% in 2006 respectively. TEB-Cast model adopted with system analysis's roles to simply accumulate and correlate all digital hourly data of plant canopy microclimates that influence the development of such disease toward a computerized model and then forecast the disease under different environmental conditions has been discussed here in detail. Field inspection's observations confirmed the accurate simulation of daily disease infection potential (DDIP), because all the observed disease appearances in tomatoes open field were correctly simulated by the model. Moreover, many attempts were done in the field of plant disease forecast worldwide, the studies of tomato early blight forecast presented here, includes Fast, Cufast and Tom-Cast models (Madden et al., 1978; Pitblado, 1992 and Gleason et al., 1995) found in agreement with the results of TEB-Cast model, that effective control of tomato early blight could be achieved when fungicides were applied according to a spray forecast model. Moreover, disease symptoms were never observed when the model did not signal a successful infection, even though the starting date for fungicide applications was accurately determined.

\section{REFERENCES}

Anonymous

(2004). FAOSTAT

data, http://faostat.fao.org/faostat/form?collection=Production

Atherton, J.G. and Rudich, J. (1986). The Tomato Crop. A scientific basis for improvement. Chapman \& Hall. London. 661 pp.

Fadl, F. A.; George, N. and El-Fangary, I. M. (1985). Chemical control of tomato early blight disease in Egypt. Agric. Res. Rev., 63; 121 126.

Foolad, M.R.; Ntahimpera N.; Christ, B.J. and Lin G.Y. (2000). Comparison between field, greenhouse, and detached-leaflet evaluations of tomato germplasm for early blight resistance. Plant Disease, 84: 967-972.

Gleason, M.L.; MacNab, A. A.; Pitblado, M.D.; Ricker, D.; East, A. and Latin, R.X. (1995).Disease warning systems for processing tomatoes in Eastern North America: Are we there yet? Plant Disease, 79: 113-121.

Horsfall, J.G. and Barratt, R.W. (1945). An improved grading system for measuring plant diseases. Phytopathology, 35: 655.

Jones, J.B.; Jones, J.P.; Stall, R.E. and Zitter, T.A. (1993). Compendium of tomato diseases. St Paul: American Phytopathological Society. 
Madden, L. V.,; Pennypacker, S. P. and MacNab A. A. (1978). FAST, a forecasting system for Alternaria solani on tomato. Phytopathology 68:1354-1358.

Pitblado, R.E.(1992). The development and implementation of TOMCAST: A weather-timed fungicide spray program for field tomatoes. Ministry of Agriculture and Food, Ontario, Canada.

Rotem, J. (1998). The Genus Alternaria: Biology, Epidemiology and Pathogenicity. APS Press, St. Paul, Minnesota.

Shuman,M. and Joel Lee. (1995). Integrating a host resistance factor into a potato early blight forecasting model. M.Sc. Thesis; Barbara J. Christ and Stanley P. Pennypacker, Thesis Co-advisors.

Vloutoglou, I. and Kalogerakis, S.N. (2000). Effects of inoculum concentration, wetness duration and plant age on development of early blight (Alternaria solani) and on shedding of leaves in tomato plants. Plant Pathology 49: 339-345.

Waals, J.E.; Denner, F. and Van Korstenal, N. (2003). Evaluation of PLANT-Plus, a decision support system for control of early blight on potatoes in South Africa. Crop Protection. Elsevier Science Ltd, Oxford, UK. 22: 6, 821-828. 


\section{تصميم و أختبار صلاحية نظام التتبؤ المرضى ( تيب ـ كاست)

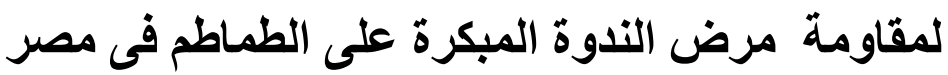 \\ محسن عبد الرازق عفيفى ، سحر عبده زيان ، مجدى عبد اللطيف امام

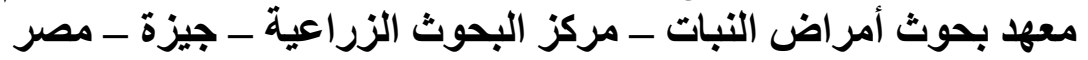

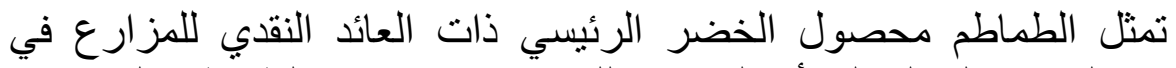

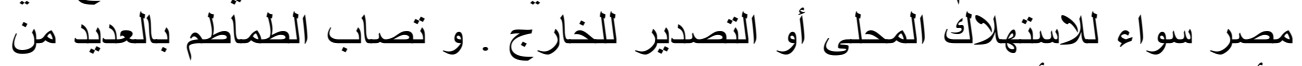

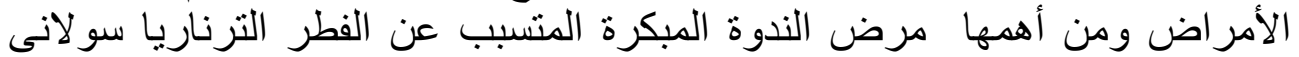

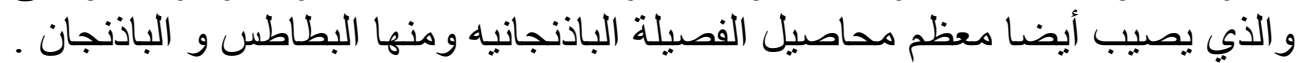

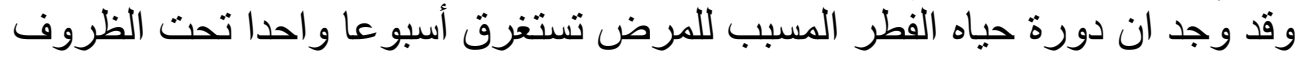

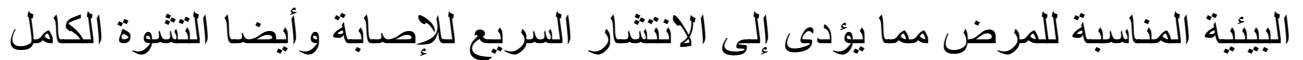

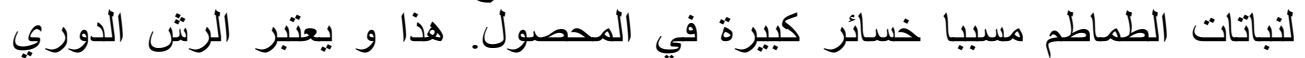

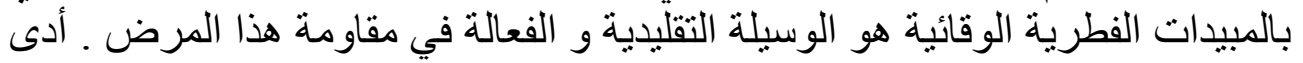

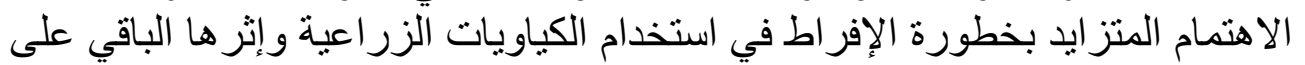

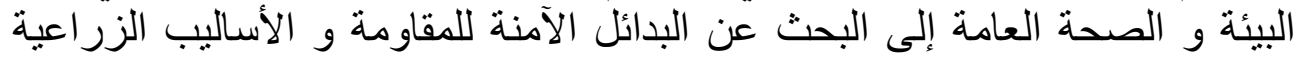

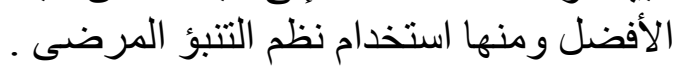

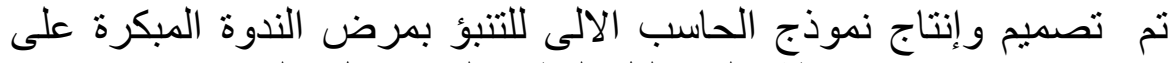

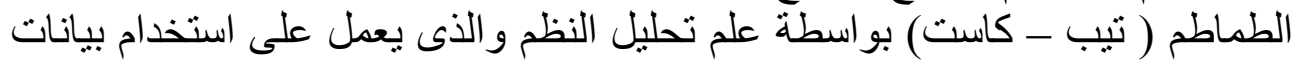

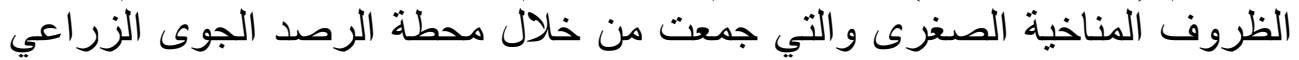

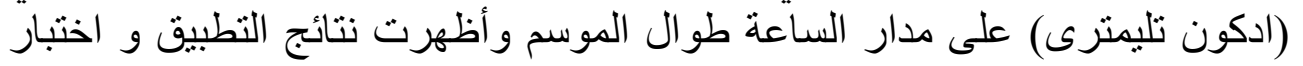

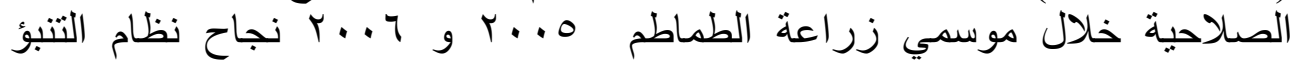

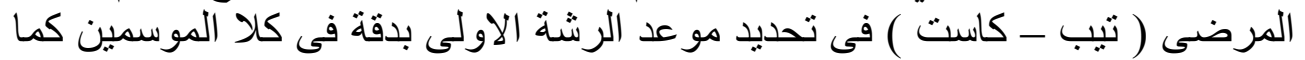

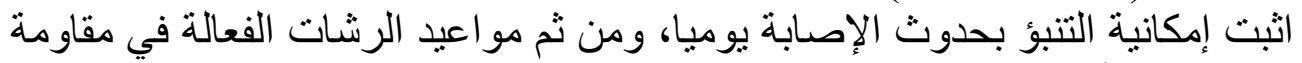

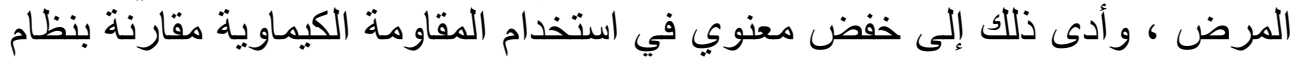

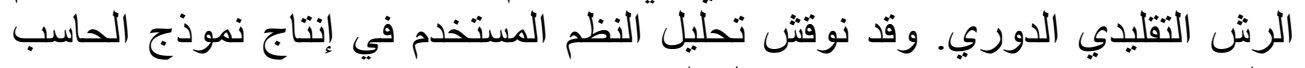
الالى ( تيب-كاست ) تفصيلا من خلال البحث . 